\title{
HYVÄ ISÄNTÄ VAI KEHNO RENKI
}

\section{- KRIITTISIÄ NÄKÖKULMIA VERKKOPEDAGOGIIKKAAN}

\author{
Teknisten innovaatioiden asemasta käydään ikuista polemiikkia: \\ Määräävätkö ne ihmistä vai ihminen niitä? Ovatko niiden sovellutukset \\ enemmän hyödyksi vai vahingoksi? Tekniikka on vain ihmisen pidennetty \\ käsivarsi. Tässä artikkelissa kirjoittaja tarkastelee verkkopedagogiikan \\ kritiikkiä neljästä näkökulmasta. Ne ovat Neil Postmanin kritiikki, ope- \\ tussuunnitelmat, sosiaalisen syrjäytyminen sekä opetuksen rationaalisuus.
}

\section{TOMI KIILAKOSKI}

$\mathrm{P}$ ohdittaessa, kuinka hyvin jokin tekninen väline - sitähän verkko juuri on - soveltuu tarkoituksiimme, olemme tekemisissä välineellisen hyvyyden kanssa. Georg Henrik von Wright (51,2001) määrittelee välineellisen hyvän eroavan muista hyvyyden lajeista. Tällöin sanotaan jonkin olion "palvelevan hyvin jotakin tarkoitusperää”. Teknisen hyvyyden vastinparina käytetään vuorostaan termejä "huono" tai "kehno". Kysyttäessä, millainen väline verkko opetuksen tai kasvatuksen näkökulmasta oikein on, kysytään samalla, kuinka hyvin verkko palvelee päämäärään pyrkimisen välineenä. Tutkitaan esimerkiksi, kuinka hyvin ihmiset oppivat sen avulla, miten tietty tietomäärä saadaan sen avulla siirrettyä ihmisten päihin, kuinka paljon kustannuksia säästetään käyttämällä tätä välinettä eikä perinteistä leuka ja liitu -menetelmää. Valitettavan harvoin kysytään, onko verkko-opetus tai opetusteknologia miellyttävä väline opettajan käyttöön. Toisinaan kasvatuspuheessa sekoitetaan väline ja päämäärä toisiinsa. Ajatellaan välineen tuottavan automaattisesti tiettyjä tuloksia eli oletetaan kausaaliketjuja, joita ehkä ei ole olemassakaan.

Kotimaisessa kasvatustieteellisessä keskustelussa verkkopedagogiikkaan on liittynyt voimakkaita toiveita. Verkon ajatellaan demokratisoivan opetuskeskustelut ja poistavan kiusalliset valtasuhteet, koska verkkokeskustelussa ei ole läsnä ulkoisia tunnusmerkkejä (Manninen \& Nevgi 2000, 100). Verkon koetaan suorastaan vaativan ajatusten reflektointia. Pienetkin lapset pystyvät sen avulla kiinnittämään huomiota omaan oppi- misprosessiinsa monessa ulottuvuudessa (Ojala \& Siekkinen 1997, 145). Usein toistuva klisee on ajasta ja paikasta riippumattomuus sekä rajattomuus tiedon haussa (esim. Järvelä 1997, 99). Välineen rajattomuuden teema toistuu myös vuorovaikutuksen tarkastelussa, koetaan esimerkiksi, että verkkoaineistoon sisäänrakennetussa vuorovaikutuksessa ja sen aktivointitehossa on rajana lähinnä mielikuvitus (Lindh \& Parkkonen 2000, 155). Kasvatuksellisessa puheessa elää voimakkaana ajatus, että tuomalla koulutukseen erilaisia tietoteknisiä ratkaisuja saadaan aikaan hyviä tuloksia. Keskustelu saattaa lähestyä teknologista determinismiä, jossa ajatellaan välineen määräävän yhteiskunnan tai oppimisen suunnan.

Kiertäessäni työssäni erilaisia oppilaitoksia kuulen usein opettajien sanovan: "Pakkohan tietokoneet on ottaa mukaan opetukseen." Eräs tapa muotoilla teknologiainnostuksen ongelma onkin kysyä, kuka tai mitkä voimat tämän pakon asettavat. Miksi meidän on niin helppo mukautua tähän pakkoon? Miksi meidän on hankala paeta tätä vääjäämättömyyttä?

\section{VERKOSTOITUVA YHTEISKUNTA}

Elämme aikaa, jolloin modernin ajan ja ajattelutavan puitteissa syntynyt koululaitos on uusien paineiden edessä. Kannetaan huolta kansallisesta kilpailukyvystä ja Suomen mahdollisuuksista menestyä globaalissa talouskilvassa. Enenevässä määrin koulutuksen tehtävä on tuottaa riittävän osaavaa työvoimaa työmarkkinoille. Huippukoulujen tulisi tuottaa huippuosaajia. Kilpailuky- 
ky sidotaan tietoyhteiskuntaan. Manuel Castells esittää yhteiskuntajärjestyksen muuttuneen 1970luvulta lähtien. Castells katsoo, etteivät aiemmat hierarkiset rakenteet enää olleet kilpailukykyisiä. Uuden informaatioteknologisen vallankumouksen tuoma verkostoyhteiskunnallinen muutos aiheutti muutoksia paitsi poliittisessa myös taloudellisessa toiminnassa.

Castellsin mukaan menestyminen kansainvälisessä talouskilvassa edellyttää kykyä verkostoitua ja olla osana erilaisia maapallon laajuisia verkostoja. Castells näkee perinteisten modernien rakenteiden, kuten kansallisvaltion ja poliittisten puolueiden, olevan kriisiytymässä. Tulevaisuuden työntekijäkunta jakautuu uudelleen verkoston jäseniin, joustajiin ja työttömiin. (Castells 2000, 251-279.) Nykyisyyden ja yhä keskeisemmin tulevaisuuden kansallisen kilpailukyvyn kannalta on merkittävää, että kansakunnan jäsenet kykenisivät olemaan jäseninä tai ainakin sopeutujina globaaleissa verkostoissa.

Castells näkee internetin ja ylipäätään informaatioteknologian - johon hän lukee myös geeniteknologian - olevan keskeisessä asemassa nykyisessä talousjärjestyksessä. Mikäli kansallisen kasvatuksen tavoitteena pidetään menestyksekkäiden huippuosaajien tuottamista, on välttämätöntä, että ihmisillä on kykyä omaksua tietoverkkojen käyttötapoja. Suomalaisen yhteiskunnan kehittymisen edellytykseksi nähdään se, että ihmiset omaksuvat verkostoitumisen kulttuurisia taitoja teknisten taitojen ohella (esim. Lehtinen \& Sinko 1998, 21-23). Kiinnostusta tietoverkkoihin voidaan perustella sosiaalisilla seikoilla: tietoverkkojen avulla voitaisiin ratkaista rakenteellisia ongelmia, kuten alueellista epätasa-arvoa (Castells \& Himanen 2001, 120-123). Mikäli Castellsin esittelemät kehityslinjat jatkuvat, tulee entistä keskeisemmäksi osata luoda oppivia verkostoja. Esimerkkinä tästä ovatkin koulujen tietotekniset sovellukset. Eräänä selittävänä tekijänä suomalaisten huomattavalle menestykselle informaatiokilvassa, Nokia etunenässä, Castells ja Himanen näkevät suomalaisten epätavallisen innostuksen teknologiaan. Heidän mukaansa suomalaiseen identiteettiin kuuluu myönteinen suhtautuminen teknologiaan. (Sama, 141-142.)

Jos siis tietoverkkojen hyödyntäminen on keskeistä kansainvälisen kilpailukyvyn turvaamiseksi ja suomalaisten yritysten toimintaedellytysten luomiseksi, ei ole hämmästyttävää, että koulutukselliset tietoverkkojen sovellukset kiinnostavat tavattomasti. Aikakautena, joka korostaa taloudellista toimintakykyä yhä keskeisempänä kasvatustavoitteena, suhtaudutaan myönteisesti innovaatioihin, jotka edesauttavat tähän pääsyä.

\section{TEKNOLOGISOITUVA KULTTUURI}

Moderni aikakausi toi muassaan vakaan uskon siihen, että kokoamalla ja soveltamalla tietoa voitaisiin tuottaa parempi tulevai-

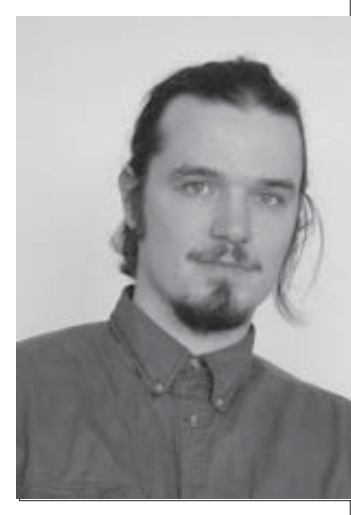

Tomi Kiilakoski suus. Tiedon teknologiset sovellukset ovat keskeisiä koko modernin yhteiskunnan kehkeytymiselle. Hivenen kärjistäen voidaankin väittää, ettei kulttuurimme ole ymmärrettävissä, ellei meillä ole käsitystä, millä tavoin kulttuurimme suhtautuu teknologiaan. Nähdäkseni tämän tarkasteleminen taloudellisen kilpailukyvyn ohella on ensiarvoisen tärkeätä sen ymmärtämiseksi, miksi kasvatuksen teknologisista sovelluksista ollaan kiinnostuneita.

Tekniikan filosofiassaan Martin Heidegger katsoi modernin teknologian tuottavan uudenlaisen suhtautumisen luontoon ja toisiin ihmisiin. Heideggerin ajattelussa modernin teknologinen lähestymistapa välineellistää ja esineellistää tarkastelemansa ilmiöt. Ilmiöistä tulee tällöin teknologian kautta välittyneitä. Heideggerin mukaan tekniikka otetaan turhan absoluuttisena. Meiltä puuttuu kyky suhteuttaa teknologiaa tai teknologis-rationaalista ajattelua muuhun kuin tekniikkaan. Asioita tutkitaan teknologian määrääminä. Teknologia paljastaa asiat teknologisesti tulkittavina. Tekninen ajattelutapa ei läpäise ainoastaan tekniikan sfääriä, vaan ulottuu myös taiteeseen ja politiikkaan - ylipäätään kulttuuriin (ks. Taminiaux 1997, 183).

Heideggerin kuulun väittämän mukaan emme ymmärrä teknologian olemusta. Arkiymmärryksessämme teknologiaa määrittää toisaalta antropologinen aspekti - tekniikka on ihmisen tekemää - ja toisaalta instrumentaalinen aspekti - teknologia on väline teknologian ulkopuolelta asetettuihin päämääriin. Heidegger pyrkii omassa teoriassaan osoittamaan, etteivät nämä väittämät kuvaa koko totuutta teknologiasta. Teknologia voidaan ymmärtää paljastumisena, Gestell- ilmiönä. Heidegger esittää, että vanhan myllyn ja tuulivoimalan välillä on selkeä ero. Siinä missä mylly 
otti energiansa virrasta, mutta ei pyrkinyt tekemään virtaa tietynkaltaiseksi, on Heideggerin mukaan modernin tuulivoimalan merkkinä se, että tuulivoimalassa tuuli on olemassa tuulen energian muokkaamista varten. Moderni teknologia asettaa hyödyntämänsä kohteet teknologiaa varten. Tämän Heidegger katsoo määrittävän myös ihmistä. Ihminen voidaan muokata tai ihmistä voidaan tarkastella teknologian keinoin. Teknologiassa kaikki on laskettua, mitattua - mysteeriä ei ole. Heideggerin terminologiassa teknologia paljastaa ilmiöt tietynkaltaisena. Maata pidetään mineraalivarastona, maatalous on muuttunut mekaaniseksi elintarviketeollisuudeksi. (Heidegger 1977, 14-15.) Teknologinen ajattelutapa estää ihmistä tarkastelemasta itseään muun kuin teknologian kautta. Ihminen asettuu Heideggerin mukaan teknologiseksi suureeksi, mitattavaksi yksiköksi. Vaarana hän näkee, että muut olemisen tavat katoavat ihmisen ulottuvilta. (Sama, 27.)

Verkkopedagogiikkaan sovellettuna tämä merkitsee, että ihmistä tai hänen oppimistaan ruvetaan tarkastelemaan teknologisena suureena, jonakin mitä voidaan mitata tarkoin mittayksiköin ja joka näin muodoin on verrattavissa toisiin samanlaisiin suureisiin. Esimerkkinä tästä ovat standardoidut monivalintatestit, joiden avulla on esitetty voitavan arvioida tiedon muistamista ja ymmärtämistä (Kiviniemi 2000, 126-127). Teknologian myötä luontoa on nähty entistä enemmän suurena varantona, ehkäpä myös ihmisiin asennoidutaan laskettavina suureina. Sinällään tämä ei tietenkään kuvaa ainoastaan verkkopedagogiikan näkemystä, vaan myös muuta koulutuksen mekaanista järjestämistä. Teknologiaa voitaisiin tietenkin puolustaa sanomalla, että sen ansiosta kaikki toimii hyvin. Ihmisillä on aiempaa paremmat mahdollisuudet esimerkiksi lisääntyneen lääketieteen ja elinmukavuuksia parantavien apparaattien kautta. Heidegger näkee kuitenkin asian toisin.

\begin{abstract}
"Kaikki toimii hyvin. Sehän juuri on kammoksuttavaa, että kaikki toimii ja toiminta vaatii yhä lisää ja laajempaa toimintaa ja tekniikka nostaa ihmisen yhä kauemmas maasta ja katkaisee hänen juurensa. ...Ihminen on jo riistetty juuriltaan. Meillä on enää vain teknisiä suhteita." (Heidegger 1997, 188.)
\end{abstract}

Heideggerin suhtautumista teknologiaan voidaan luonnehtia teknologiakriittiseksi, ehkä jopa pessimistiseksi. Heidegger näkee teknologian tuovan mukanaan tukun vaaroja, joita aiempi maailma ei pitänyt sisällään. Hätkähdyttävää hänen mielestään on, että olemme sokeita tekniikalle eikä meillä ole kykyä ymmärtää sitä, saati luoda sille vastapoolia. Tekniikka on tapa paljastaa asioita ja ilmiöitä. Tekniikka, joka Heideggerille on länsimaisen metafysiikan lopullinen muoto, on tapa ottaa haltuun asioita muuttamalla niitä teknisiksi suhteiksi ja mekaanisiksi suureiksi. Lopulta joudutaankin kysymään, mitä tekniikan ulkopuolelle jää tai onko meillä kykyä katsoa asioita tekniikan ulkopuolelta. Heideggerin tekniikan filosofia jättää perinnökseen pulman, onko kysymyksiin "Mitä ihminen on?" tai "Miten ihmiseksi kasvetaan?" löydettävissä vastaus teknisen ajattelutavan ulkopuolelta.

Heideggerin esittämä kritiikki on liitettävissä perinteeseen, jossa katsotaan valistuksen järjen ideaalien tulleen tulkituksi lähinnä välineellisen järjen kautta. Yhteiskunnan ja ihmisen vapauttamisen sijaan valistus toi muassaan paljon järjettömyyttä. Heideggerin aikalainen ja kiistakumppani Theodor Adorno näki, että teknologinen rationaalisuus on noussut ainoaksi rationaalisuuden muodoksi. Max Weberin termejä käyttäen instrumentaalinen järki, välinerationaalisuus, oli vallannut alaa päämäärärationaalisuudelta yhä uusilla elämäalueilla.

\section{TARVITSEMME MUITAKIN KUIN VÄLINEELLISIÄ IHMISSUHTEITA}

Ihmisten väliset suhteet perustuvat ideaalisimmillaan vastavuoroiseen suhteeseen, jossa kummallakin osapuolella on mahdollisuus ja oikeus vaikuttaa kohtaamiseen. Kummankin osapuolen oikeudet on tunnustettu ja tunnistettu. Martin Buber nimittää tämänkaltaista suhdetta Minä-Sinä suhteeksi. Tälle vastakohtaista tapaa, jossa tarkastelija on tarkastelemansa kohteen ulkopuolella ja ei anna tälle sille kuuluvaa arvoa, Buber nimittää Minä-Se -suhteeksi. Adornon mukaan teknologinen kehitys on tuottanut tilanteen, jossa teknologia yhä useammin pakottaa ihmiset ottamaan paitsi luontoon, myös toisiinsa Minä-Se suhdetta. Teknisemmin ilmaisten Adornon kanta on, että tekniikan edellyttämä subjektin suhde objektiin määrittää myös ei-teknisiä suhteita. Adorno on tämän suhteen pessimistinen. Hänen mukaansa valistuksen lupaus maanpäällisestä onnelasta ei ole toteutunut, vaan tilalle on tullut teknisen järjen hallinta (Adorno \& Horkheimer 
1989, 37-41). Vaikkakin Adornon ja Buberin filosofioiden välillä on tärkeitä eroavaisuuksia, voidaan nähdäkseni Adornon keskeistä huolenaihetta tarkastella Buberin avulla. Buber näkee keskeiseksi, että meillä on myös Minä-Se -suhteita. Kulttuurimme edellyttää, että suhtaudumme välineellisesti paitsi ympäristöömme, myös toisiin ihmisiin. Täysi ihmisyys edellyttää kuitenkin muitakin kuin välineellisiä suhteita. "Ilman Sitä ihminen ei voi elää. Mutta joka elää pelkästään Sen kanssa, ei ole ihminen.” (Buber 1999, 58.)

Siinä missä Buber, pelkää Adornokin modernin teknis-rationaalisen asenteen riistävän meiltä kyvyn aitoon ihmisyyteen. Adornon ajattelussa teknis-rationaalinen sfääri latistaa ihmisiä siinä mitoin, että aito yksilöllisyys on kateissa. Tämä näkyy arkielämän ohella taiteissa, kuten musiikissa (Adorno 1973, 7-11). Adornon huolenaiheena olikin, että teknologia kaappaa alleen yhä uusia alueita ja alistaa kaikki ihmisten väliset suhteet teknologian sanelemiksi. Tyypillinen esimerkki tämänkaltaisesta suhteesta on virastojen henkilökunnan suhtautuminen asiakkaisiinsa: nämä ovat numeroita ja suureita, eivät verta ja lihaa olevia hengittäviä olentoja. Martin Jayn (1974, 261) mukaan Adorno ja Horkheimer ajattelivat että valistuksen tapa suhtautua luontoon - alempana ja vähempiarvoisena - alkoi entistä selvemmin kuvata myös ihmisten välisiä suhteita. Myös ihmiset muuttuivat hallinnan kohteiksi.

Adornon mukaan valistus sisälsi paljon järjettömyyden siemeniä. Valistus nosti antroposentrisesti esille ihmisen ja sulkeisti luonnon, samoin kuin kaavasta poikkeavat yksilöt. Ilmeinen esimerkki tästä ovat juutalaiset. Adorno näki Max Weberiä seuraten instrumentaalisen rationaalisuuden kaapanneen voimakkaan otteen koko länsimaisesta elämäntavasta. Weberin mukaan teknis-rationaalinen elämäntapa lepää mekaanisella perustalla, itseään vahvistaen. Alun perin kapitalistinen elämänasenne oli kuin mantteli, joka tuli riisua pois siirryttäessä henkisiin toimiin. Weberin mukaan "kohtalo teki manttelista teräksenlujan kotelon" (Weber 1990, 135).

Adornon mielestä yhteiskunnalliset rakenteet heijastuvat myös ihmisten psyykkisiin rakenteisiin. Kulloinenkin yhteiskunnallis-kulttuurinen tilanne tuottaa tietynlaisia rakenteita. Adorno lukikin natsismin mahdollisuuden olleen kiinni siitä, että silloinen maailma oli tuottanut persoonallisuuksia, joiden oli mahdollista tulla keskitysleirin kannattajiksi. Adornon mukaan psykologi- set tekijät kykenivät motivoimaan ihmisiä järjettömyyksiin. Osansa tästä oli tekniikalla ja teknisellä suhtautumistavalla.

"Nykymaailma, jossa tekniikka on avainasemassa, tuottaa teknologisia, teknologian kanssa yhtä jalkaa kulkevia ihmisiä. Tällä on omat hyvät puolensa: ihmiset eivät ole niin helposti huiputettavissa omalla alallaan, ja tämä voi vaikuttaa yleisemminkin. Toisaalta nykyisessä suhtautumisessa tekniikkaan on jotakin liioittelevaa, irrationaalista ja patogeenistä. Tämä liittyy niin sanottuun "teknologiseen harhaan", ihmiset ovat taipuvaisia pitämään tekniikkaa asian varsinaisena ytimenä, itsetarkoituksena, jolla on oma olemus, ja sen vuoksi he unohtavat, että se on vain ihmisen pidennetty käsivarsi. Välineet - ja tekniikka on eräs väline, jolla ihmislaji pyrkii säilyttämään itsensä-fetisoituvat, koska päämäärä - ihmisarvoinen elämä - hämärtyy ja katoaa ihmisten tietoisuudesta." (Adorno 1995, 241-242.)

Adorno kuvaa prosessia, jossa hankalat päämääräkysymykset korvataan huomattavasti helpommilla välinekysymyksillä. On helpompi kysyä, minkälaisilla välineillä ihmistaimen kasvua voitaisiin edesauttaa kuin kysyä, minkä takia ja mihin tätä taimea oikein kasvatetaan. Välineiden fetisoituminen päämääriksi on kasvatuksen historiassa pitkä prosessi.

\section{TEKNOLOGIAN KASVATUKSELLISET SOVELLUKSET}

Larry Cuban on tutkinut, millä tavoin erilaiset teknologiset innovaatiot on otettu vastaan koulutuksessa ja kasvatuksessa. Jokainen teknologinen media on tuonut myötään suuria toiveita siitä, miten luokkahuoneopetusta voidaan elävöittää ja sen kauan tiedettyjä ongelmia voitaisiin lieventää ottamalla käyttöön uusia keksintöjä. Cubanin tutkimustulokset näyttävät tukevan väitettä, että koulutuksen tarkasteleminen tapahtuu usein tekniikkaa ja metodeja koskevien kysymysten ohjaamana (Giroux 2001, 103).

Cubanin mukaan teknologisten keksintöjen, elokuvan, radion ja myöhemmin television vastaanotto on sujunut nelivaiheisesti. Ensimmäisessä vaiheessa uuden teknologian opetukselliset sovellukset nähtiin voimakkaan positiivisina. Uudistajat olivat kasvatusta suunnittelevia vir- 
kamiehiä ja teknologian valmistamiseen osallistuneita toimijoita. Toisessa aallossa tuotettiin akateemisia tutkimuksia, joissa todisteltiin uuden teknologian etua suhteessa tavanomaiseen kouluopetukseen. Huomionarvoista Cubanin mukaan on, etteivät opettajat osoittaneet ennakkoon suurta innostusta uuden teknologian käyttöönottoon. Kolmantena vaiheena olikin tutkimuksinkin todennettu pettymys esimerkiksi tekniseen käyttöönottoon, teknisiin ongelmiin, soveltumattomuuteen luokkahuoneopetukseen ja olemassaoleviin opetussuunnitelmiin. Viimeisessä vaiheessa tuotettiin tutkimustietoa, joissa valiteltiin sitä, että uutta teknologiaa käytettiin satunnaisesti luokkahuoneessa. Valitteluja ja parjaamista kohdistettiin sekä kalliita investointeja tehneisiin suunnittelijoihin että jääräpäisiin opettajiin. (Cuban 1986, 5-6.) Cubanin mukaan leimallista on, ettei missään vaiheessa juurikaan kysytty, tulisiko uusi teknologia ylipäätään ottaa käyttöön. Suurin virhe kulloisessakin teknologisessa uudistuksessa on, ettei niitä käyttöönottaessa pyritty tarkastelemaan asioita opettajien perspektiivistä, vaan ne tuotiin opetukseen ulkoapäin teknologisen katsantokannan dominoimana.

Cubanin kuvaamaa innostusta, jonka taustalla on tulkintani mukaan välineellisen järjen voimakas korostuneisuus kasvatuksessa, voidaan havaita yllättävillä tahoilla. Keksijä Thomas Edison ajatteli vuonna 1922 elokuvan korvaavan oppikirjat lähimmän kymmenen vuoden aikana kokonaan (Cuban 1986, 9). Saksalaisen sivistysajattelun perillinen Erik Ahlman $(1993,113)$ näki vuonna 1937 kasvatuksen edistyneen nimenomaan kasvatustekniikan kehittymisenä, joka korvasi aiemmat teknillisinä toimenpiteinä epäkelvot kasvatusperinteet. Keksijöiden ja filosofien jakamaa instrumentaalisen järjen kunnioitusta luonnehtikoon behavioristipsykologi B.F. Skinnerin mietteet koululaitoksen uudistamisesta teknologian avulla:

"In the light of our present knowledge a school system must be called a failure if it cannot induce students to learn except by threatening them for not learning. That this has always been the standard pattern simply emphasizes the importance of modern techniques... Aversive practices can not only be replaced, they can be replaced with far more powerful techniques. " (Skinner 1958, 977.)

Skinnerin näkemykset tuntuvat hätkähdyttävän ajankohtaisilta. Skinner arvostelee koulukasvatusta paitsi heikosta kyvystä saada tuotettua oppilaidensa teknisiä valmiuksia myös moraalisesti vääristä, inhottavista menetelmistä. Kouluopetuksen ongelmiin Skinner tarjoaa ratkaisuiksi kehittynyttä teknologiaa. Nykyään ajatellaan verkon auttavan tiellä kohti asiantuntijuutta helpottaen tutkivaa oppimista, itsesäätelytaitoja, tehtäväorientoitunutta motivaatiota, yhteisöllistä oppimista sekä oppimisen ja asiantuntijoiden kulttuurien lähentämistä (Hakkarainen \& Järvelä 1999, 246-256). Verkkokeskustelussakin näkyy länsimaille tyypillinen välineellisen järjen korostaminen ja luottamus, että koulutuksen ongelmat ovat sen avulla ylitettävissä.

\section{VERKKOTEKNOLOGIAN KRITIIKIN SUUNTAUKSIA}

Teknologialuottamuksen ohella verkkopedagogisessa keskustelussa esiintyy myös kriittisiä näkökulmia, jotka olen luokitellut neljään ryhmään, joissa arvostelu kohdistuu kehnouteen välineenä, verkon opetussuunnitelmallisiin seurauksiin, tietokoneiden opetuskäytön sosiaalisiin seurauksiin sekä yleiseen opetuksen rationalisoitumiseen. Yhteistä näille on, että ne näkevät tietoverkot kehnona renkinä, huonona välineenä kasvatuksellisten päämäärien saavuttamiseen. Jokainen niistä lähtee siitä, että verkkoteknologia tuottaa seurauksia, jotka eivät ole pedagogisesti tai sosiaalisesti toivottavia.

\section{Postmanilainen kritiikki}

Neil Postmanin ajattelu pohjaa teesiin, että väline on samalla viesti. Tällä tarkoitetaan sitä, että lähetetty sanoma muuttaa muotoaan riippuen siitä mediumista, jolla se välitetään. Sama sisältö on erilainen tv:ssä ja savumerkein lähetettynä, joita kumpaakin osa ihmiskunnasta on käyttänyt viestien välittämiseen. Postman on kulttuuripessimisti, jonka ajattelussa välineen arvostus on riippuvainen siitä, kuinka paljon kukin väline sallii tilaa korkeakulttuurille. Postman ottaa esimerkin Yhdysvaltain presidentinvaaleista vuodelta 1858 . Tuolloin ehdokkaina olleiden Abraham Lincolnin ja Stephen A. Douglasin väliset retoriset mittelöt saattoivat kestää seitsemänkin tuntia. Tavallisella yleisöllä oli tuolloin kykyä ja sinnikkyyttä seurata esiintyjien sanataidonnäytteitä (Postman 1987, 49-50). Postmanin tulkinnan mukaan tilan- 
teen mahdollisti se, että ihmiset olivat tottuneita typografiseen ilmaisuun. Vaikka keskustelijat puhuivatkin tekstinsä, oli siinä voimakas kirjallinen säväys.

Postmanin mukaan nykykulttuurissa, johon olennaisesti on vaikuttanut televisio, ei vastaavaan ilmaisun laveuteen päästä. Poliitikkojen puheita näytetään tv:ssä vain muutamia sekunteja - muutoin ihmiset kyllästyisivät. Postmanin mukaan tv:tä riivaa nopeus ja halu varmistaa, etteivät ihmiset pääse pitkästymään. Postman ajattelee, että muuttuneet mediat ovat tuoneet mukanaan muuttuneen tai rappeutuneen kyvyn seurata vaikeita asioita. Tv:n ohella tietotekniset sovellukset ovat olleet Postmanin kritiikin kohteina. Postmanin mukaan informaatioteknologia saattaa tuottaa kasvatuksellisesti haitallisia seurauksia, mikäli sen puitteita ei analysoida riittävällä tavalla (Postman 1996, 43-45). Eräänä ilmentymänä Postmanin kuvaamasta prosessista voitaneen pitää Jean Baudrillard'n nimeen liitettyä ajatusta siitä, että nykykulttuurissa ei ole mitään aitoa tai edes aidon kopioita, on vain kopion kopioita. Baudrillard'n kolmannen asteen simulaatiossa maailma täyttyy kopioista, joilla ei ole mitään alkuperäistä taustallaan. Koulutuksessa tämä voi näyttäytyä opetuskeskustelujen muuttumisena simulaatioiksi. On kuin teknologian välityksellä keskusteltaisiin, mutta todellisuudessa luodaan vain simulaatioita keskusteluista.

Postman on voimakkaasti kritikoinut länsimaista kulttuuria siitä, että se ottaa teknologian annettuna niin pitkälle että inhimillinen edistys samaistetaan teknologisiin innovaatioihin (Postman 1993, 117). Opetussuunnitelmassa ei pidetä keskeisinä arvoja tai sivistyksen sisältöjä, tuotetaan vain kasvatuksellinen supermarket, jossa asiakkaat voivat noukkia ostoskärryihinsä mitä haluavat. Postmanin mukaan teknologisoitunut koulutus tuottaa arvotyhjiön. Postman näkee, että aito koulutus voi lähteä ainoastaan motivaatiosta, siitä, että ihmisillä on tarve ja halu oppia koulutuksen kohteena olevaa asiaa. Pelkkä teknologia ei riitä oppimisen lähteeksi, vaaditaan jotakin muuta - jotakin mitä olemme kadottaneet. Vaikka ei jakaisikaan Postmanin kulttuuripessimismiä, voi hänen välineiden viestiluonnetta koskevista huomioista silti oppia jotakin. Tärkeimpänä seikkana voidaan kysyä, ollaanko riittävässä määrin selvillä tämänkaltaisista median itsensä aiheuttamista rajoituksista.

\section{Opetussuunnitelmallinen kritiikki}

Virtuaaliopetuksen nostattamia opetussuunnitelmallisia kysymyksiä ei juuri olla huomioitu yleisessä keskustelussa. Itse näen tämän kritiikin ulottuvuuden tärkeänä. Suurena kysymyksenä verkkopedagogiikassa pidän sitä, missä määrin joidenkin oppilaitosten käyttämät amerikkalaisen kulttuurin puitteissa syntyneet oppimisalustat ja organisoinnin tavat ovat sovellettavissa suomalaiseen koulutuskulttuuriin. Verkkoympäristön suunnittelu pitää sisällään monia pedagogisia ratkaisuja. Jos nämä ratkaisut tehdään yhden opetuskulttuurin piirissä, on vaarana, että kasvatus yhdenmukaistuu ja eri koulutuskulttuurien erot häviävät (ks. Burbules 2000, 346). Perinteisessä amerikkalaisessa opetussuunnitelma-ajattelussa on pyritty luomaan järjestelmiä, joissa yksittäisellä opettajalla ei ole mahdollisuutta vaikuttaa opetussuunnitelmaan. Maassa on perinteenä, että opetussuunnitelma tehdään virkamiestyönä. Yksittäisen opettajan tekemiä opetussuunnitelmallisia ratkaisuja pyritään kontrolloimaan siten, että opettajilla on mahdollisimman vähän mahdollisuuksia joko tuoda opetussuunnitelmaan joitakin sisältöjä tai viedä jotakin pois. Klassisen opetussuunnitelman mallin on tehnyt Ralph W. Tyler, jonka rationaali on siirtynyt myös suomalaisen didaktiikan perinteeseen. Tässä mallissa (Tyler 1969) erotetaan opetussuunnittelun tasoina 1. tavoitteiden asettaminen, 2 . oppimiskokemusten määrittäminen, 3. oppimiskokemusten organisoiminen ja 4. arviointi.

Tyler ajatteli, että luomalla keskusjohtoisesti mahdollisimman hyvin laadittu ja tieteellisesti tarkistettu opetussuunnitelma pystytään opetus organisoimaan tehokkaasti. Yksittäisten opettajien mahdollisuudet luoda tällainen suunnitelma eivät luonnollisestikaan olisi yhtä suuria. Tylerin edustaman tradition ihanteeksi on usein nähty opettajankestävä opetussuunnitelma, jossa opetusprosessin lopputuloksen kannalta on yhdentekevää, kuka opettaja kurssin kimpussa työskentelee. Tyleria on kritikoitu esimerkiksi siitä, että hänelle tavoitteet, kuten tietysti myös opetusmenetelmätkin, on asetettu oppilaille ja opettajille ulkopuolelta. Käytännössä tämä on johtanut koulutuksen suunnittelun keskittymiseen virkamieskunnalle.

Verkko-opetuksessa, jossa tähdätään mahdollisimman samankaltaiseen opetukseen kaikille, on vaarana, että ajatus opettajankestävästä opetussuunnitelmasta toteutuu kärjistetyssä muodos- 
sa. Usein verkko-opiskelussa kurssin suunnittelija ja toteuttaja ovat eri henkilö. Tällöin opetussuunnitelmallisena ratkaisuna tulee säädellä, kuinka suuri vastuu kurssin käytännön toteuttajalla on. Uhkana verkko-opiskelussa nähdään se, että se riistää opettajalta autonomian ja tekee hänestä muiden laatimien opetussuunnitelmien passiivisen toteuttajan (Apple \& Jungck 1998, 152-154).

\section{Sosiaalinen syrjäytyminen}

Tietoverkkojen käyttöä välineenä on arvosteltu siitä, että se aiheuttaa sosiaalista epätasa-arvoa. Kritiikki liittyy kahteen ulottuvuuteen: toisaalta tietyt ryhmittyvät voivat taloudellisista syistä olla estyneitä käyttämään hyväkseen tietoverkkoja ja toisaalta tietokoneiden edellyttämä ajattelutapa voi olla vieras jollekin ryhmille.

Ilmeinen sosiaalista eriarvoistumista tuottava tekijä on ihmisten erilaiset taloudelliset mahdollisuudet hankkia itselleen laitteita, joilla päästä käsiksi tietoverkkoihin. Mikäli samalla ei huolehdita infrastruktuurista, voi käydä täysin päinvastoin kuin Himanen ja Castells kaavailivat - sen sijaan, että verkko kykenisi ehkäisemään maantieteellistä eristäytymistä tapahtuukin täysin päinvastoin. Jos joko yhteydet tai laitehankinnat eivät toimi, voi verkko jo sinällään olla tuottamassa eriarvoistumista.

Michael Apple on esittänyt kriittisiä huomioita sosiaalisen syrjäytymisen näkökulmasta. Hänen mukaansa keskittyminen silkkaan tekniikkaan voi olla ongelmallista. On selvää, että kasvatuksen teknologiaan käytetyt rahavarat ovat pois jostakin muusta, esimerkiksi taidekasvatuksesta. Verkko-oppiminen myös edellyttää tietynlaista ajattelutapaa leimallisena piirteenään teknis-rationaalisuus. Verkko-opiskelua on pidetty tästä syystä sukupuolisesti potentiaalisena uhkatekijänä (Sofia 1998). Apple näkee haitallisena sen, että verkko-ohjelmistojen kehittäminen tapahtuu talouden eikä pedagogiikan ehdoilla. Pedagogisen kehittämisen vaatimukset nojaavat erilaiseen sisäiseen logiikkaan kuin markkinavetoinen opetusteknologiakehittäminen. Apple kokee verkkoopetuksen voivan lisätä opettajien työkuormaa ja vähentää mahdollisuuksia kehittää omaa työtään. Opettajat saattavat joutua nojautumaan markkinoita varten kehitettyihin valmiisiin opetuspaketteihin, joiden kasvatuksellinen arvo voi olla vähäinen. (Apple 1999, 91.)

\section{Opetuksen rationalisaatio}

Moderni yhteiskunta luo tehokkuutta rationalisoimalla erilaisia elämänalueita. Ongelmana on, että tällöin saatetaan rationalisoida elämänalueita, joille instrumentaalinen rationaalisuus ei sovi. Weberin tunnetun kuvauksen mukaan modernin yhteiskunnan asukas elää rationaalisuuden rautahäkissä, josta hänellä ei ole pakotietä. Weber, kuten moni muukin klassinen sosiologi, koki yhteiskunnallisen kehityksen vääjäämättömänä. Yksilöllä ei ole paluuta rationalisoimattomaan maailmaan. Sosiologi George Ritzer on luonut uuden kuvauksen rationalisaatiokehityslinjoista. Ritzer nostaa McDonald'sin paradigmaattiseksi esimerkiksi rationalisoidusta organisaatiosta. Ritzerin kuvauksen mukaan mcDonaldisaatio on prosessi, jonka myötä pikaruokalan periaatteet tulevat dominoimaan enemmän ja enemmän amerikkalaisen yhteiskunnan, kuten muunkin maailman, eri sektoreita. (Ritzer 2000, 1). McDonaldisaation periaatteita ovat: 1. tehokkuus, 2. laskettavuus 3. ennustettavuus, 4. kontrolloitavuus

Nämä seikat tukevat McDonaldisaatiota, ne koetaan ilmeisiksi eduiksi. Kukapa ei haluaisi, pakinoitsija Ollin sanoin, hyviä tuloksia vähällä vaivalla? Ritzerin mukaan McDonaldisoitunut maailma tuottaa ongelmia epäinhimillisyydellään. Tulevaisuuden maailma valtauttaisi ihmisiä paremmin, mikäli McDonaldisaatio ei olisi kaikkea läpäisevää.

Verkkopedagogiikkaa voidaan analysoida McDonaldisaation näkökulmasta. Usein verkkojen opetuskäyttöä perustellaan juuri tehokkuudella. Ajatellaan, että ihmisiä saadaan koulutettua juuri sillä paikalla millä he ovat, verkon välityksellä. Tausta-ajatuksena tuntuu usein olevan rahan säästäminen. Laskettavuudella viitataan siihen, että kaikki olennaiset vaikuttavat tekijät pyritään kvantifioimaan. Mikä ei ole laskettavissa, ei ole olemassa. Koska opetuksen laadun mittaaminen olisi hankalaa, on helpompi operoida mitattavilla suureilla sen sijaan, että aidossa mielessä pyrittäisiin ymmärtämään onko opetus kulloinkin laadukasta. Verkko-opetusta tarkasteltaessa voidaan kysyä, missä määrin tässä opetuskulttuurissa ilmenevät piirteet kasvattavat teknisrationaalista opettajakäsitystä, jonka ongelmina on nähty keskittyminen kontrolliin ja kuriin sekä riittämätön ymmärrys historiallisesti marginalisoituja ryhmiä kohtaan (esim. Kanpol 1999, 183). Verkoissa on laskettavissa kaikki, opiskelijan käynnit, kuinka pitkään hän on kutakin dokument- 
tia lukenut, miten monta sanaa hän on kullekin sivulle lähettänyt jne. Määrä ei silti koskaan muutu automaattisesti laaduksi. 'Paljon' ei merkitse 'hyvin'. Missään kehittyneessä oppimisen teoriassa ei puhuta suoritteiden määrästä, vaan siitä, missä määrin yksilö kykenee mukauttamaan omiin merkitysrakennelmiinsa opetuksen sisältöä.

Ennustettavuus on usein ollut massakoulutuksen tavoitteena. Verkkoon liitettyjen standarditestien myötä on entistä helpompaa tarkkailla, että kaikki ovat saavuttaneet samankaltaisia oppimispäämääriä. Kontrolli on keskeinen piirre verkkooppimisessa. Puhe siitä, kuinka koko oppimisprosessi saadaan verkko-opintojen myötä talteen, osoittaa, että kontrollifunktio on keskeinen tekijä verkko-oppimisessa ja -opetuksessa (ks. myös Sarja 2001, 206-207). Äärimmäisenä uhkakuvana kontrollin yhteiskunnassa on ajatus, että yksilöä valvotaan joka taholta voimallisin keinoin. Teknologian opetuskäyttö ei tietenkään itsessään aiheuta rationalisaatiota, sillä opetusta on jo pitkään pyritty rationalisoimaan. Verkko-opetus voi olla kuitenkin osaltaan lisäämässä opetuksen rationalisaatiota juuri siihen suuntaan, jota Adorno pelkäsi ja kammosi.

\section{LOPUKSI}

Tietoverkkojen opetuskäyttöön saatetaan suhtautua modernille kulttuurille tyypilliseen tapaan teknologisen katsantokannan sanelemana itsestäänselvyytenä. Olen pyrkinyt osoittamaan, että kulttuurillemme ja koulutukselle on tyypillistä luottamus teknologiaan. Teknologinen perspektiivi asettuu helposti etusijalle. Teknisten välineiden vastaanoton historian valossa näyttää, että kasvatuksessa on helppo huumaantua teknologiasta. Tietoverkkoihin, siinä kuin muuhunkin teknologiaan, saatetaan suhtautua päämääränä sinänsä, hyvänä isäntänä. Nähdäkseni verkon pedagoginen hyödyntäminen edellyttää rohkeutta luopua katteettomasta teknologiauskosta ja kykyä analysoida verkko-oppimisen tai peräti verkkokasvatuksen kontekstia. Välttämätöntä on välineluonteen pohtiminen.

Hyvän isännän sijaan verkosta tulisi tehdä hyvä renki. Uskon, että esittelemistäni kritiikin perinteistä voidaan löytää apua myös verkkokurssien suunnitteluun. Oleellista olisi kysyä esimerkiksi, miten verkkokeskustelun rajoitteet on huomioitu kurssin suunnittelussa; miten yksittäisen opettajan rooli mielletään; miten eri ryhmit- tymien toiminta on huomioitu; keskitytäänkö kurssin suunnittelussa ja toteutuksessa rationaalisuuden mukaisesti määrällisiin ja hallinnallisiin kysymyksiin. Olennaisena kysymyksenä pidän sitä, ollaanko suunnittelussa riittävässä määrin tietoisia teknologisten sovellusten mahdollisista haittavaikutuksista ja tähän liittyvistä yhteiskunnallisista ja kulttuurisista tekijöistä. Kuten kaikessa opetuksessa, myös verkkopedagogiikassa onnistumisen kannalta keskeisimmät kysymykset ovat luonteeltaan pedagogisia eivätkä teknisvälineellisiä.

\section{LÄHDELUETTELO}

Adorno, T. W. (1973). Philosophy of Modern Music. käänt. A.G. Mitchell ja W. V. Bloomster. Lontoo: Sheed \& Ward.

Adorno, T. W. \& Horkheimer, M. (1989). The Dialectic of Enlightenment. käänt. J. Cumming. Lontoo: Verso.

Adorno, T. W. (1995). Kasvatus Auschwitzin jälkeen. suom. R. ja E. Sironen, T. Uusitupa. S. 227-248 teoksessa J. Koivisto, M. Mäki \& T. Uusitupa (1995). Mitä on valistus?

Ahlman, E. (1993). Kasvatusedellytykset, kasvatusmenetelmät, kasvatuspäämäärät. s. 110118 teoksessa Ahlman, E.: Artikkeleita (2). Teokset IX. toim. L. Nukari. Jyväskylän yliopisto, Filosofian laitos. Julkaisu 57.

Apple, M. (1998). Teaching and Technology: The Hidden Effects of Computers on Teachers and Students. s. 314-339 teoksessa Beyer, L. \& Apple, M. (toim.1998): The Curriculum. Albany: State University of New York Press.

Apple, M. \& Jungck, S. (1998). "You Don’t Have To Be a Teacher To Teach This Unit": Teaching, Techonology, and Control in the Classroom. s. 133-157 teoksessa Bromley, H. \& Apple, M. (toim. 1998).

Apple, M. (1999). Power, Meaning, and Identity. New York: Peter Lang.

Bromley,H. \& Apple, M. (toim. 1998). Education/Techonology/Power. Albany: State University of New York Press.

Buber, M. (1999): Minä ja sinä. Suom. J. Pietilä. WSOY.

Burbules, N. (2000): Does the Internet Constitute a Global Educational Community? s. 
323-357 teoksessa Burbules, N. \& Torres, C. (2000). Globalization and Education. Lontoo: Routledge.

Castells, M. (2000): The Rise of the Network Society. Oxford: Blackwell.

Castells, M. \& Himanen, P. (2001). Suomen tietoyhteiskuntamalli. Suom. J. Kemppainen. WSOY \& SITRA.

Cuban, L. (1986). Teachers and Machines. New York: Teachers College Press.

Giroux, H. (2001). Public Spaces, Private Lives. New York: Rowman \& Littlefield.

Hakkarainen, K. \& Järvelä, S. (1999). Tietoverkot asiantuntijuuden jakamisessa ja rakentamisessa. s. 241-257 teoksessa Eteläpelto, A. \& Tynjälä, P. (toim.1999). Oppiminen ja asiantuntijuus. WSOY.

Heidegger, M. (1977). The Question Concerning Technology. Käänt. W. Lovitt. s. 3-36 teoksessa The Question Concerning Technology and Other Essays. New York: Harper \& Row.

Heidegger, M. (1997): Enää Jumala voi meidät pelastaa. Suom. T. Vaden. s. 171-202 teoksessa Steiner, George (1997). Heidegger. Gaudeamus.

Jay, M. (1974). The Dialectical Imagination. Lontoo: Heineman.

Järvelä, Sanna (1997): Tietokoneavusteinen intentionaalinen oppimisympäristö osana kemian tutkivaa oppimisprojektia. s. 85-101 teoksessa Lehtinen (toim. 1997).

Kanpol, B. (1999): Critical Pedagogy. Lontoo: Bergin \& Garvey.

Kiviniemi, K. (2000). Johdatus verkkopedagogiikkaan. Keski-Pohjanmaan ammattikorkeakoulu.

Lehtinen, E. (toim. 1997). Verkkopedagogiikka. Edita.

Lehtinen, E. \& Sinko, M. (1998). Bitit ja pedagogiikka. Jyväskylä: Atena.

Lindh, K. \& Parkkonen, M. (2000). Oppimateriaali verkossa. s. 147-159 teoksessa Matikainen \& Manninen (toim. 2000).

Manninen, J. \& Nevgi, A. (2000): Opetus verkossa - vuorovaikutuksen uudet mahdollisuudet. s. 93-109 teoksessa Matikainen \& Manninen (toim. 2000).
Matikainen, J. \& Manninen, J. (toim. 2000). Aikuiskoulutus verkossa. Helsingin yliopisto, Lahden tutkimus- ja koulutuskeskus.

Ojala, M. \& Siekkinen, M. (1997). Tietotekniikan perusteista, sovelluksista ja haasteista alle kouluikäisten lasten opetuksessa ja oppimisessa. s. 143-158 teoksessa Lehtinen (toim. 1997).

Postman, N. (1987). Huvitamme itsemme hengiltä. Suom. I. Rekiaro. WSOY.

Postman, N. (1993). Technopoly. New York: Vintage Books.

Postman, N. (1996). The End of Education. New York: Vintage Books.

Ritzer, G. (2000): McDonaldization of Society. Lontoo: Sage Publications.

Sarja, J. (2001): Vapaa sivistystyö vapaana myös netissä. s. 195-215 teoksessa Sallila, P. \& Kalli, P. (2001): Verkot ja teknologia aikuisopiskelun tukena. Aikuiskasvatuksen 42. vuosikirja. Kansanvalistusseura ja Aikuiskasvatuksen tutkimusseura.

Skinner, B.F. (1958). Teaching Machines. s. 969-977. Science October 24.

Sofia, Z. (1998). The mythic machine: gendered irrationalites and computer culture. s. 29-53 teoksessa Bromley,H. \& Apple, M. (toim. 1998)

Taminiaux, J. (1997): Gestell ja Ereignis. Suom. M. Lehtinen. s. 183-203 teoksessa Haapala, A. (toim.): Heidegger. Ristiriitojen filosofi. Gaudeamus.

Tyler, R. (1969): Basic Principles of Curriculum and Instruction. Chicago: The University of Chicago Press.

Weber, M. (1990). Protestanttinen etiikka ja kapitalismin henki. Suom. T. Kyntäjä. WSOY.

Wright, G.H. von (2001). Hyvän muunnelmat. Suom. V. Oittinen. Otava.

Artikkeli saapui toimitukseen 23.5.2002.

Se hyväksyttiin julkaistavaksi toimituskunnan kokouksessa 16.12.2002. 